\title{
Risk estimation for future glacier lake outburst floods based on local land-use changes
}

\author{
S. Nussbaumer ${ }^{1}$, Y. Schaub ${ }^{1}$, C. Huggel ${ }^{1}$, and A. Walz ${ }^{2}$ \\ ${ }^{1}$ Department of Geography, University of Zurich, Zurich, Switzerland \\ ${ }^{2}$ Institute for Earth and Environmental Science, University of Potsdam, Potsdam, Germany \\ Correspondence to: Y. Schaub (yvonne.schaub@geo.uzh.ch)
}

Received: 19 July 2013 - Published in Nat. Hazards Earth Syst. Sci. Discuss.: 30 August 2013

Revised: 26 March 2014 - Accepted: 23 April 2014 - Published: 27 June 2014

\begin{abstract}
Effects of climate change are particularly strong in high-mountain regions. Most visibly, glaciers are shrinking at a rapid pace, and as a consequence, glacier lakes are forming or growing. At the same time the stability of mountain slopes is reduced by glacier retreat, permafrost thaw and other factors, resulting in an increasing landslide hazard which can potentially impact lakes and therewith trigger far-reaching and devastating outburst floods. To manage risks from existing or future lakes, strategies need to be developed to plan in time for adequate risk reduction measures at a local level. However, methods to assess risks from future lake outbursts are not available and need to be developed to evaluate both future hazard and future damage potential.

Here a method is presented to estimate future risks related to glacier lake outbursts for a local site in southern Switzerland (Naters, Valais). To generate two hazard scenarios, glacier shrinkage and lake formation modelling was applied, combined with simple flood modelling and field work. Furthermore, a land-use model was developed to quantify and allocate land-use changes based on local-to-regional storylines and three scenarios of land-use driving forces. Results are conceptualized in a matrix of three land-use and two hazard scenarios for the year 2045, and show the distribution of risk in the community of Naters, including high and very high risk areas. The study underlines the importance of combined risk management strategies focusing on land-use planning, on vulnerability reduction, as well as on structural measures (where necessary) to effectively reduce future risks related to lake outburst floods.
\end{abstract}

\section{Introduction}

High-mountain systems worldwide are changing at a rapid pace as a result of climate change (WGMS and UNEP, 2008; Clague et al., 2012). Glacier shrinkage is the most visible indicator of change (Gardner et al., 2013) but permafrost thaw has similarly been observed in many regions (Harris et al., 2009). For the Alps a drastic reduction of glacier extent and volume is projected for the 21st century (Zemp et al., 2007; Linsbauer et al., 2013). Climate-induced changes involve a number of hazards, including unstable slopes resulting in landslides, avalanches and debris flows which might impact high-mountain lakes and therewith trigger outburst floods from recent or new glacier lakes (Stoffel and Huggel, 2012; Haeberli, 2013). Many events in the past several decades have demonstrated the impact of glacier lake outburst floods (GLOFs) on people and assets. Single events killed up to several thousand people and caused damages of the order of tens of millions USD (Carey, 2005; Huggel et al., 2011).

In Switzerland new glacier lakes are of particular concern, as many lakes are currently forming or will form in the future in some glacially carved topographic depressions parallel to glacier retreat (Künzler et al., 2010). Models of ice thickness and glacier shrinkage indicate potential sites of future glacier lake formation over large parts of the Swiss Alps (Frey et al., 2010; Haeberli and Linsbauer, 2013). Many of them will be located in an unstable environment, e.g. underneath steep, destabilized slopes, and are therefore prone to impacts from mass movements which could trigger a GLOF. In the densely populated Swiss valleys, large damage potential would face such an event. To adequately handle these situations, the new lakes should be included into risk management as early as 
possible, given that planning of mitigation measures often requires a lot of time.

Statistical and empirical methods have been developed to evaluate the probability and intensity of glacier lake outbursts for the hazard estimation (Huggel et al., 2004; McKillop and Clague, 2007). To more accurately estimate the spatial distribution of the outburst flood and the aggregated inundation intensities, numerical models have been proved useful in several case studies (Osti and Egashira, 2009; Worni et al., 2012). First rough-scale modelling of outburst floods have already been performed for future lakes in Switzerland (Frey et al., 2010), but there is a lack of assessment of future damage potential and related risks of GLOFs.

One of the challenges of anticipatory risk management is to integrate future physical hazards with future damage potential, given future socio-economic conditions. In fact, potentially exposed assets such as mountain communities, tourism or energy structures undergo changes and continuous development. To project socio-economic conditions and exposure into the future, land-use modelling is typically applied, following a number of storylines (e.g. Bouwer et al., 2010). In Switzerland, land-use scenarios have been generated at the national scale (e.g. Wissen Hayek et al., 2011), yet downscaling to the local scale remains challenging (e.g. Walz et al., 2013).

Reduction of important existing gaps was attempted in this study with respect to local-scale future risks from lakes in deglaciated areas concentrating on the case study of the Grosser Aletsch Glacier region and therein on the community of Naters. The objective of this study was (1) to develop a feasible methodology for the evaluation of future risks related to GLOF hazards for a local Alpine setting by assessing changes in hazards and land use; and (2) to apply the methodology to the case study of Aletsch/Naters (Valais, Switzerland). Both the methods and the results should be of use for medium- to long-term planning, and allow anticipating risk reduction. Accordingly, the two time horizons addressed are the years 2021 and 2045.

The assessment of future conditions and risks inherently implies uncertainties, including those related to hazards and land-use changes. The assessment of future GLOF hazards is carried out based on glacier modelling, indicating sites and volumes of future glacier lakes (Linsbauer et al., 2013) and flood modelling after Huggel et al. (2003) combined with field work. To model spatially explicit, local land-use scenarios for 2045 a scenario analysis in combination with quantification and allocation of potential land-use storylines was employed. This is a common approach (e.g. Cammerer et al., 2012; Walz et al., 2007), which combines the advantages of both explorative scenario analysis and, the more formal, rulebased land-use change modelling. Explorative scenario analysis covers the principal storylines in socio-economic development and addresses directly the crucial drivers of land-use change in the study regions. To quantify land-use changes for each scenario, changes are related directly to drivers of land- use change, similar to Alcamo (2001). Rule-based modelling provides transparency in the allocation of land-use change. Here a high degree of thematic differentiation within the settled area is aimed at. This degree of differentiation is highly desirable for local risk assessment, as it improves indications on future values and persons at risk (BAFU, 2011).

\section{Study area and data}

Naters is a municipality in the canton Valais in Switzerland at an altitude of $673 \mathrm{~m}$ a.s.l. It is a typical Swiss dormitory town; most of the people work in bigger towns nearby. In the last decade a considerable increase in population has taken place, as Naters has become a zone of attraction, especially to people from adjacent small villages. About $90 \%$ of Naters' 8300 inhabitants live in the valley bottom where also extensive agriculture is conducted. The valley is crossed by the rivers Rhône and Massa and surrounded by steep slopes (Swisstopo, 2010; Fig. 1a). The Massa flows to Naters from the reservoir lake Gibidum, which retains the melt water of the Aletsch Glacier.

Potential locations and approximate volumes of future lakes in the Aletsch glacier area are based on recent studies investigating glacier bed topography and simulating glacial retreat over the next several decades (Linsbauer et al., 2013). These data were available in GIS format and represented the starting zones for potential GLOFs. As outlined in Fig. 1a, the risk study area concentrates on the Massa River channel and the flat part of Naters, where most people live. It is defined by the intensity maps of potential GLOF, including outburst scenarios of 4 million $\mathrm{m}^{3}$ (Fig. 1b) and 20 million $\mathrm{m}^{3}$ (Fig. 1c).

Interviews with local authorities were conducted in July 2011 to better understand the processes and limitations of land-use changes in the municipality of Naters. Interviewees represented the local planning department and the government of Naters.

Spatially explicit storylines of future land-use changes within the region were modelled on the basis of national survey data from the two survey periods 1979-1985 (BFS, 1986) and 1992-1997 (BFS, 1998). The Swiss land-use statistics differentiate between 45 categories, which were reclassified into nine classes (Table 1) identified as most relevant for risk assessment within this study, namely "multifamily house", "single-family house", "mixed use" (such as business buildings or parks), "industry", "railway", "roads", "agriculture", "forest", and "unproductive area" (such as water bodies or bedrock).

The Swiss land-use statistics were complemented up to 2009 through mapping of land-use changes based on a field survey, the interviews with local authorities and the most recent topographic maps (Swisstopo, 2010).

Estimation of economic values of the different landuse classes were adopted from the official Swiss platform 


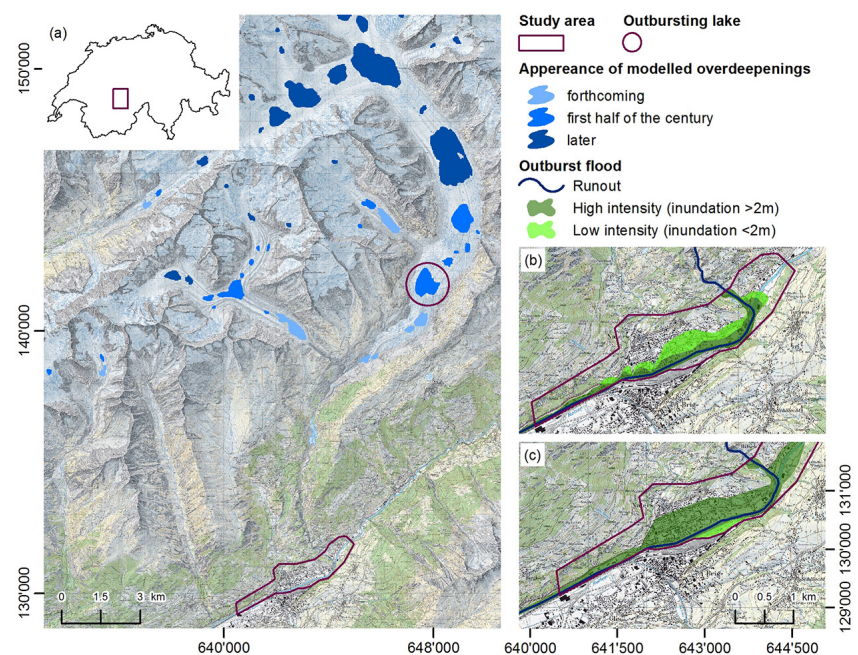

Figure 1. (a) Location of the risk study area in Naters, Switzerland and of modelled overdeepenings in the glacier beds in the Aletsch Glacier area, which are assumed potential sites of future lake formation (Linsbauer et al., 2013). Integration of the intensity maps elaborated for the outburst scenarios of 4 million $\mathrm{m}^{3}$ (b), and 20 million $\mathrm{m}^{3}$ (c). DEM25 reproduced with permission of Swisstopo (BA110005).

for assessment of efficiency of protection measures against natural hazards "EconoMe" (BAFU, 2011). The visualization of the socio-economic scenarios and the GLOF modelling rested upon the digital elevation model with $25 \mathrm{~m} \mathrm{ac}-$ curacy (DEM25), provided by Swisstopo (2010).

\section{Methodology}

In order to estimate the risk of a GLOF in Naters under future conditions, a three-step methodology was developed (Fig. 2). First, socio-economic scenarios were generated and different driving forces were identified and quantified. This information was implemented in a second step into the land-use scenario modelling. Finally, scenario-based land-use transitions were combined with flood hazard to risk estimations.

\subsection{Socio-economic scenario development for land-use changes in Naters}

The exploratory scenarios (see Carter et al., 2001) were developed (Fig. 3) following the approach of Wissen Hayek et al. (2011). The goal of the present scenario development was to elaborate plausible land-use storylines for the municipality of Naters until 2045 which cover a wide range of fundamental uncertainties in regional socio-economic development and associated land-use changes. Extrapolation of the current state of land use served as a baseline scenario.

The most relevant drivers of regional development, landuse changes and the potential development pathways for Naters were identified based on a literature review (CIPRA,
Table 1. Reclassification of the land-use classes by BFS (2011). The abbreviations will be used further on in the document. To simplify, $\mathrm{MFH}, \mathrm{SFH}$, and Mix will also be merged to settlements.

\begin{tabular}{|c|c|}
\hline $\begin{array}{l}\text { Reclassified } \\
\text { land-use classes }\end{array}$ & $\begin{array}{l}\text { Description } \\
\text { (original land-use class number) }\end{array}$ \\
\hline $\begin{array}{l}\text { Multi-family house } \\
\text { (MFH) }\end{array}$ & $\begin{array}{l}\text { Multi-family houses, backyards } \\
(27,47)\end{array}$ \\
\hline $\begin{array}{l}\text { Single-family house } \\
\text { (SFH) }\end{array}$ & $\begin{array}{l}\text { Single-family houses, } \\
\text { agricultural buildings, } \\
\text { backyards, allotment gardens } \\
(25,28,45,52)\end{array}$ \\
\hline $\begin{array}{l}\text { Mixed use } \\
\text { (Mix) }\end{array}$ & $\begin{array}{l}\text { Mixed use, backyards, sports areas } \\
(29,49,51)\end{array}$ \\
\hline Settlements & MFH, SFH, Mix \\
\hline $\begin{array}{l}\text { Industry } \\
\text { (Ind) }\end{array}$ & $\begin{array}{l}\text { Industry, industrial railways, } \\
\text { repositories, diggings } \\
(21,41,64,65)\end{array}$ \\
\hline $\begin{array}{l}\text { Railway } \\
\text { (Rail) }\end{array}$ & $\begin{array}{l}\text { Train station area, railways, green areas } \\
(35,36,67)\end{array}$ \\
\hline $\begin{array}{l}\text { Roads } \\
\text { (Road) }\end{array}$ & $\begin{array}{l}\text { Roads, parking lots, green areas } \\
(33,34,68)\end{array}$ \\
\hline $\begin{array}{l}\text { Agriculture } \\
\text { (Agri) }\end{array}$ & $\begin{array}{l}\text { Sparse orchards, gardenings, } \\
\text { meadows, pasture lands } \\
(77,78,81,82,83,84,85,86,87,88,89)\end{array}$ \\
\hline $\begin{array}{l}\text { Forest } \\
\text { (For) }\end{array}$ & $\begin{array}{l}\text { Open and closed forests } \\
(11,12,13,14,15,16,17,18,19)\end{array}$ \\
\hline $\begin{array}{l}\text { Unproductive area } \\
\text { (Unprod) }\end{array}$ & $\begin{array}{l}\text { Glaciers, water, rocks, open vegetation } \\
(90,91,92,95,97,99)\end{array}$ \\
\hline
\end{tabular}

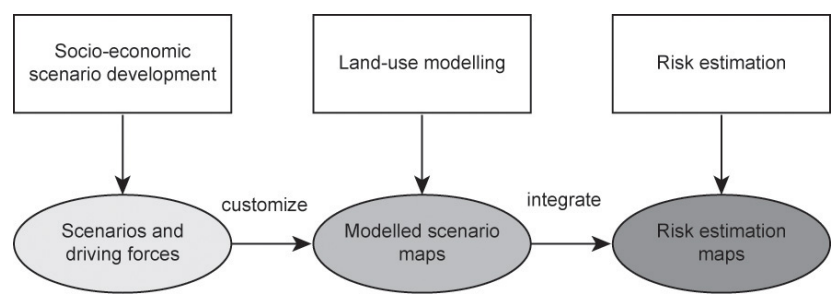

Figure 2. Simplified overview of the methodology.

2010; OcCC, 2007; BUWAL, 2003; IPCC, 2012; Voigt et al., 2010), as well as on interviews with representatives of the local planning authority and government (Michlig, 2011; Holzer, 2011). The driving forces and the development pathways were then combined into three land-use scenarios. The scenario storylines could per se not be validated, but plausibility checks were performed by cross-checking the scenarios with other scenarios for Swiss mountain regions (ARE and UVEK, 2008; Leitungsgruppe des NFP 48, 2007; Wissen Hayek et al., 2011; Walz et al., 2007). 


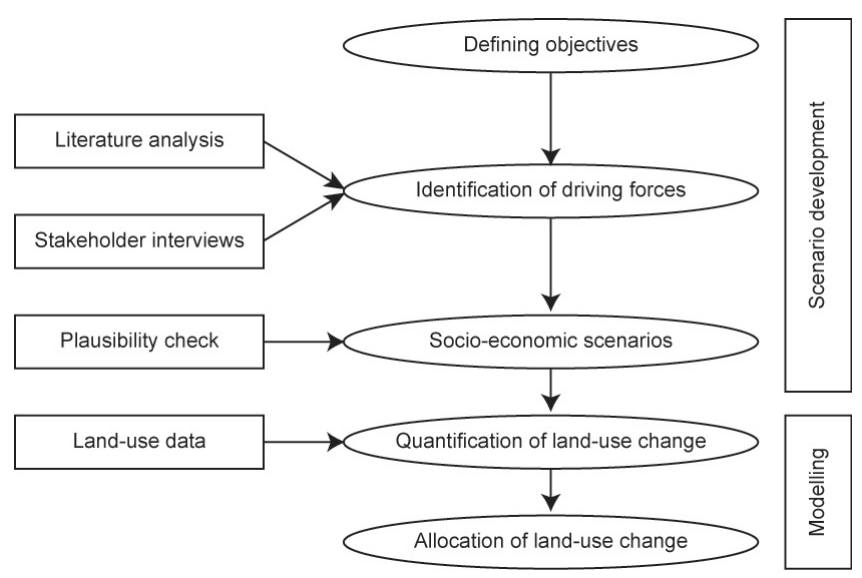

Figure 3. Procedure for generating scenarios.

\subsection{Land-use modelling: quantification and allocation of changes}

Similar to other studies (Walz et al., 2007), land-use modelling was performed by first quantifying land-use transition rates and then allocating the changes in space.

\subsubsection{Quantification of land-use changes}

Methods to quantify land-use changes based on socioeconomic scenarios are manifold. Approaches include for instance participatory processes (e.g. Walz et al., 2007), economic-based modelling (e.g. Britz et al., 2011; Briner et al., 2012), agent-based modelling techniques (e.g. Fontaine and Rounsevell, 2009) and conditional extrapolation of recent trends (e.g. Soares-Filho et al., 2006). In the present study, the three socio-economic scenarios were translated to land-use change rates by (a) extrapolation of the observed changes for the trend scenario ["o"] and (b) by conditional adaptation of these rates based on the quantification of driving forces in the two further scenarios ["+"] and ["-"]. These scenarios will be explained in more detail in Sect. 4.1. This approach combined the advantages of explorative and rule-based approaches.

Here, land-use transition rates were estimated for two 12year steps (1997-2009 for validation and 2009-2021) followed by a 24-year step (2021-2045). Because uncertainties increase in future, a 24-year step was chosen instead of two 12-year steps. For this purpose, the observed transition rates from past changes between the two available landuse data sets were first extrapolated for the trend scenarios "o" (BFS, 1986, 1998). These rates were limited to the legal planning constraints in particular relevant for settlement expansion (Michlig, 2011). For the two further scenarios "+" and "-", rates of land-use change were estimated by quantifying driving forces based on the assumption in the socioeconomic scenarios. Again, these rates were limited to legal constraints. A constant building density was assumed for all cells of the settlement related land-use classes.

\subsubsection{Interaction between land-use classes}

Land-use classes interacted with each other where expansion of one land-use class happened at the cost of another one. "Agriculture" and "settlements" (including "multifamily houses", "single-family houses" and "mixed use") as an example interacted strongly with each other. "Forest" interacted with "agriculture" while "industry" and "roads" partly interacted with "settlements". Within "settlements" the increase of "mixed use" areas was highly dependent on the increase of "multi-family houses" and "single-family houses": An increasing number of inhabitants also requires e.g. more businesses, schools or retreat homes.

The plausibility of the resulting transition rates was tested by comparing the defined rates of change to recent studies of Swiss land-use changes (Walz et al., 2007; BUWAL, 2003; ARE and UVEK, 2008; Leitungsgruppe des NFP 48, 2007; OcCC, 2007; CIPRA, 2010). These studies were also consulted to determine the transformation rates between certain land-use classes (e.g. from "agriculture" to "mixed use").

\subsubsection{Allocation of land-use change}

The final step of the land-use modelling was to allocate landuse transition across the landscape based on the following:

- Only cells within the current legally defined construction areas could be transformed to any kind of settlement because of legal constraints (ARE and UVEK, 2008) and because no adaptation of these construction areas was assumed for the future (Michlig, 2011).

- Certain land-use classes were assumed constant (i.e. "unproductive areas", "roads", "railways" or "bridges") due to topography and lifetime restrictions, and certain land-use classes could only be changed into one direction, i.e. "agriculture" to "settlements" and one type of "settlements" into another type of "settlements" (e.g. "multi-family houses" to "single-family houses"). Exception were "roads" and "unproductive areas" within areas with housing settlements, where an aggregation of the buildings provoked a change within the "roads" or "unproductive area" cells transforming them into "settlement".

- The transition into certain land-use classes was determined by the land use of the neighbouring cells to support clustering of same land use in line with the federal land-use planning guidelines (ARE and UVEK, 2008).

For validation the simulated trend scenario between 1997 and 2009 was compared with the most recent topographical maps based on 2009 aerial photographs (Swisstopo, 2010). 


\subsection{Risk estimation}

The UNISDR (2009) defines risk as the combination of the probability of an event and its negative consequences. For assessment of natural hazards in Switzerland, this concept was defined as the product of the frequency of a hazardous scenario and the damage potential (Bründl et al., 2009). In the following, the definition of the involved parameters and the risk assessment approach are outlined.

\subsubsection{Hazard}

Recent studies indicate that new lakes with volumes of up to 170 million $\mathrm{m}^{3}$ may form in the area of Grosser Aletsch Glacier over the next 100 years as a result of glacier retreat (Linsbauer et al., 2013). For the purpose of the present study an outburst of a potential new lake, which is expected to have reached a volume of about 20 million $\mathrm{m}^{3}$ by 2045 (Linsbauer et al., 2013), was assumed (Fig. 1a). The exact lake outburst mechanisms obviously cannot be predicted, but both evidence of existing landslides (Strozzi et al., 2010) and an expected further destabilization of slopes due to glacier retreat (Haeberli et al., 2010; Huggel et al., 2012; Schaub et al., 2013) suggest that impacts from landslides into the lake and thus-produced displacement waves and outburst floods may be a realistic scenario.

The frequency of a hazardous event is usually expressed as the probability of occurrence or the return period (Bründl et al., 2009). Indicating a return period is not possible for non-stochastic events, such as a lake outburst flood. More feasible is an approximation of probabilities by using outburst scenarios, as suggested by Schneider et al. (2014). Accordingly, two outburst flood scenarios were defined on the basis of two different outburst volumes for the same lake, 4 and 20 million $\mathrm{m}^{3}$, representing partial (higher probability) and full drainage (lower probability), respectively. In a first stage a simple flow-routing model was applied (Huggel et al., 2003) to assess the approximate extent of downstream flooding for a lake outburst from the identified lake (Fig. 1a). This GIS-based model distributes flow and mass movements downstream according to geometric and topographic criteria, and thus makes it possible to assess areas potentially affected by an outburst flood.

Layers with different flood height intensities were then evaluated in the field and in GIS for each outburst scenario, based on the calculation of the maximum flood runoff after Huggel et al. (2002) and the flow capacity of open channels and overspill after Henderson (1966). Two different intensity classes were distinguished for each outburst flood scenario. These classes build on the official Swiss guidelines (Loat and Petracheck, 1997), which differentiate between high intensity for an inundation height of $>2 \mathrm{~m}$ and medium intensity for inundation height $\leq 2 \mathrm{~m}$ (Fig. $1 \mathrm{~b}$ and c). Eventually, simple flow dynamics were assessed, in particular flow velocities and flow travel times from the initiation of the outburst flow to the impact in Naters. Calculations are based on published GLOF flow velocities (Cenderelli and Wohl, 2001; Schneider et al., 2014) considering a flow travel distance of $14 \mathrm{~km}$.

\subsubsection{Damage}

According to Bründl et al. (2009) the damage potential consists of the product of four parameters: (1) the exposure probability of an object/person while a scenario is occurring; (2) the spatial probability that an object/person is directly affected by the scenario; (3) the loss, consisting of the value of the object/number of persons exposed; and (4) the vulnerability of an object/the lethality of a person against the impact of the event. For the future-oriented risk estimation approach presented here, the parameters were treated as follows.

The exposure probability of objects and even more of persons depends on the exposure situation. It would be necessary to define several exposure scenarios, such as an outburst flood during a football match in the sports ground next to the river Rhône. For scenarios in the future a detailed exposure analysis would introduce an unreasonable level of additional uncertainty, and therefore a constant exposure situation was considered, with all objects and persons expected to be present (e.g. during daytime of a regular working day).

The spatial probability is more variable for other processes than floods, such as snow avalanches or rock falls. Here, the flood is assumed to appear over the entire area considered in the intensity maps, therefore a spatial probability of 1 is assigned to every object/person, and the parameter is not discussed further.

The different categories of variable loss (number of objects and persons) were not monetized but were classified independently of each other. The values were assigned to each cell of an ArcGIS raster, applying the four-level scale 1 = "low", 2 = "medium", 3 = "high", and 4 = "very high" (Table 2). Scores for the object values were defined according to the EconoMe database (BAFU, 2011). For persons the scores were estimated as a function of the population density per land-use class. Mortality was not considered in this approach, as it is too variable to be adequately implemented for this purpose.

The definition and use of vulnerability varies substantially in the literature, but recent major references define it as the propensity to be adversely affected, or the characteristics of a person or system that make it susceptible to damaging effects of hazards (UNISDR, 2009; IPCC, 2012). When it comes to the implementation of vulnerability in a risk assessment and mapping study it is useful to distinguish between different types of vulnerability, namely between physical and social vulnerability (Bara, 2010; Hegglin and Huggel, 2008).

Social vulnerability can be understood as the ability of a person or a group to cope with loss (Cutter et al., 2009). To estimate the social vulnerability in Naters the following factors were considered: economic conditions (wealth), age, nationality and insurance cover. The classification into different 
Table 2. Allocation of the assessment variables into a four-level scale. Intensity is defined by the inundation depth. Allocation of the land-use classes differs between object value and number of persons present for loss, and between physical and social vulnerability respectively. For explanation of the abbreviations see Table 1.

\begin{tabular}{|c|c|c|c|c|c|}
\hline \multirow[t]{2}{*}{ Scale } & \multirow{2}{*}{$\begin{array}{l}\text { Intensity } \\
\text { inundation }\end{array}$} & \multicolumn{2}{|c|}{ Loss } & \multicolumn{2}{|c|}{ Vulnerability } \\
\hline & & Object value & Persons & Physical & Social \\
\hline $1=$ low & & Agri, For, Unprod & Agri, For, Unprod & Mix, Ind & Agri, For, Unprod \\
\hline $2=$ medium & $\leq 2 \mathrm{~m}$ & Mix, Ind, Road, Rail & Ind, Road, Rail & Road & Road, Rail \\
\hline $3=$ high & & SFH & SFH, Mix & SFH, MFH, Rail & SFH, Mix, Ind \\
\hline $4=$ very high & $>2 \mathrm{~m}$ & MFH & MFH & Agri, For, Unprod & MFH \\
\hline
\end{tabular}

vulnerability classes was done based on available literature (Nöthiger et al., 2002; Kantonsforstamt St. Gallen, 2011; Burgerschaft Naters, 2011; BFS, 2011; OcCC, 2007) and interviews with community leaders (Michlig, 2011), which were also used to eventually assign social groups to the landuse categories. According to that, "multi-family houses" are more vulnerable than "single-family houses". Uninhabited land-use categories such as agricultural or forest areas were classified as low social vulnerability (Table 2 ). In addition to the area-wide social vulnerability classification, specific and particularly vulnerable locations were flagged in the final risk map (Fig. 7) such as schools, churches or sports grounds (Bara, 2010).

Physical vulnerability was defined as the degree of physical impairment an object experiences when affected by a particular hazard process (BAFU, 2011). The values for physical vulnerability are related to the hazard magnitude according to Bründl et al. (2009). These values were derived from EconoMe (BAFU, 2011) for each land-use class with respect to high-intensity debris flows. In consideration of the unknown development of the physical vulnerabilities in the future (e.g. through variations in construction techniques), a simplified approach was applied using only one set of values independent of the hazard intensity. This definition resulted, for instance, in high physical vulnerability values for landuse categories such as "agriculture", "forest", and "unproductive land use", even though they are located at the margin of potentially flooded areas. Specifically, the values for "mixed use", "roads", "industry", "railway", and "unproductive area" were estimated by averaging the EconoMe values of similar land-use classes (e.g. values for streets $(0.7)$ were represented in EconoMe by values for motorways (0.45), municipal roads $(0.65)$, and rural roads $(0.95)$ ). To be consistent with the other semi-quantitative input grids to the final risk assessment, the assigned scores had to be reclassified to a four-level semi-quantitative scale, with EconoMe values of low (0) to very high (1) vulnerability where 0 means no impairment and 1 means total destruction. The final classification of land-use classes is provided in Table 2.

\subsubsection{Risk}

Risk is a function (product) of hazard and damage potential as outlined above. In this study all variables were classified qualitatively into an ordinal scale ranging from "low" to "very high", which basically inhibits a mathematical multiplication of the values. Instead a matrix-based risk estimation as suggested by Mergili and Schneider (2011) was applied.

Three matrices according to the first example in Fig. 4 were composed for vulnerability (axes: social and physical vulnerability), loss (axes: value of objects and number of persons) and damage potential (axes: vulnerability and loss). Each matrix thus spans a space of 4 by 4 cells, with each axis ranging from 1 (low) to 4 (very high). The allocation of values for each cell in the matrix is based on the average of the corresponding axes values, but actually involves a subjective decision. Therefore, two versions of the final risk matrix (axes: hazard and damage potential) were defined (Fig. 4), that should demonstrate the effect of matrix definition on the final risk result.

\section{Results}

\subsection{Socio-economic scenarios}

The reclassified land-use data set from 1997 showed an increase in "settlements" of $+63 \%$ or 12 ha and a decrease in the category "agriculture" of $-18 \%$ or 14 ha as compared to 1985 (Fig. 5). These results were confirmed by findings from field surveys, the interviews with the local authorities and recent topographic maps (Swisstopo, 2010), which corroborated the increase of settlements and decrease of agriculture after 1997 in Naters. Based on this, the following factors were identified as exerting the strongest influence on landuse changes in settlements and agriculture in Naters and were thus defined as driving forces of the socio-economic scenarios:

- Agriculture: the steep slopes in Naters with extensive agriculture are currently subsidized by the government. A cutback of the subsidies would lead to abandonment of the agricultural land what would imply 


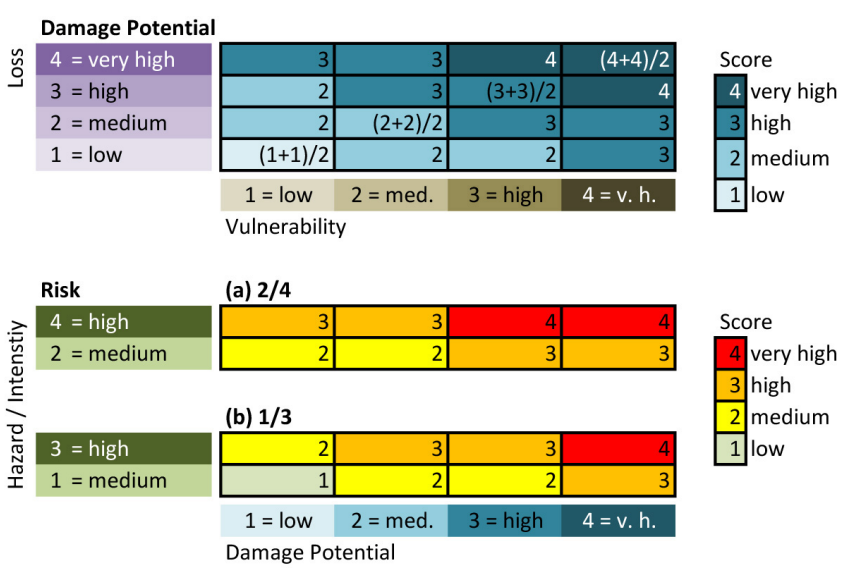

Figure 4. Matrix-based definition and weighting of risk classes. The risk parameters loss, vulnerability and the resultant damage potential were assessed according to the first matrix, which illustrates the example of damage potential derivation. Risk was assessed according to the matrices (a) and (b) considering the damage potential and two quantifications of the hazard. The scores are a result of the mean of the value of both axes (rounded), as illustrated by means of four cells in the first matrix.

growing forest areas as well as an unattractive landscape (Hunziker, 1995), resulting in less tourism in the area.

- Economic situation: Naters has experienced an economic upturn during the last 15 years which, amongst other effects, led to strong and increasing construction works in the area. A possible stagnation of the national economic situation would slow down the construction activities, and a downturn would highly constrain them.

- Tourism: tourism and economy are closely linked in Naters. An upturn in tourism would imply a strong increase in businesses; a downturn would imply abandoned businesses.

The driving forces and their interactions refer to implications for land use (Table 3), which can be consolidated in the three scenarios "o", "+", and "-" summarized in the following storylines:

Scenario "o" is a business-as-usual scenario. It represents the continuation of the current trends of land use until 2045 and is considered the most likely scenario by stakeholders of Naters. There are no radical changes foreseen in any land-use class. The trend of an increase in the category "settlements" at the expense of "agriculture" in the legally defined zone of construction, which was observed in the past, will continue for the next 10 years. Especially "single-family houses" will rise in numbers, whereas in "mixed use" a moderate growth is expected. In "multi-family houses" the least increase in settlements is predicted due to compaction of the construction. After 2021 the rate of building construction will correlate with the rate of economic development.
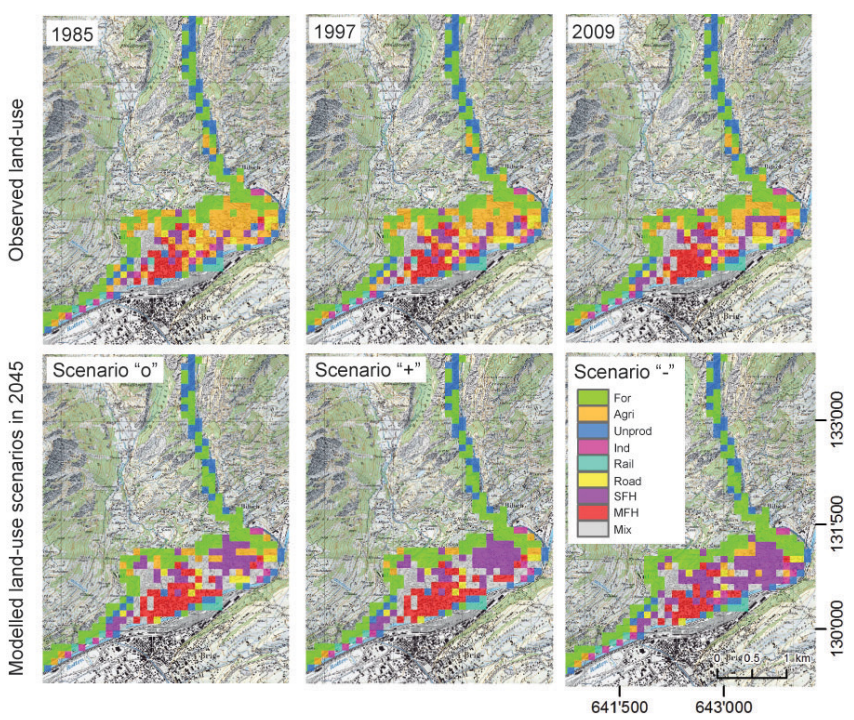

Figure 5. Reclassified land-use data sets of 1985, 1997 and 2009 in Naters (upper row). Modelled land-use scenarios for 2045 (lower row). DEM25 reproduced with permission of Swisstopo (BA110005) and BFS (1986, 1998). For explanation of the abbreviations see Table 1.

Scenario "+" is marked by a strong increase in building constructions until 2045, particularly within "single-family houses" and "mixed use", as a consequence of a stable and prosperous economic situation. The growing tourism sector will benefit from winters with less snow, since parts of the municipality Naters include high-elevation winter tourism areas, which are likely to attract tourists who used to visit skiing destinations located at lower elevations. This development will lead to an increase in business constructions, as well as in new public buildings, such as schools or retirement homes. The area within the current construction zone not yet covered with buildings will be developed on a constant rate until 2045.

Scenario "-" is characterized by a decrease in construction activities from 2021 on due to an economic downturn. However, a few settlements will still be built, such as public buildings and "single-family houses" by people not negatively affected by the economic crisis. The tourism sector will decrease, implying abandonment of businesses locations. Furthermore, subsidies to agriculture will no longer be provided by the government. As a consequence, forest areas will increase and landscape may lose attractiveness, which again might result in a decrease in tourism.

\subsection{Land-use modelling: quantification and allocation}

All simulations showed an increase between 3 and $40 \%$ in "settlements" (consisting of "multi-family houses", "singlefamily houses" and "mixed use") for all scenarios over the entire time span. The increase of these change rates, however, slowed down after 2009 (Table 4). In all scenarios 
Table 3. The development pathways of major driving forces and their implications for land use within the three scenarios "o", "+" and "-".

\begin{tabular}{|c|c|c|c|}
\hline Driving forces & Scenario "o" & Scenario "+" & Scenario "_" \\
\hline $\begin{array}{l}\text { Subsidization agriculture } \\
\text { Implications for } \mathrm{L} / \mathrm{U}\end{array}$ & $\begin{array}{l}\text { business as usual } \\
\text { decreasing agriculture }\end{array}$ & $\begin{array}{l}\text { business as usual } \\
\text { decreasing agriculture }\end{array}$ & $\begin{array}{l}\text { cutbacks } \\
\text { abandoning agriculture, } \\
\text { increasing forest area }\end{array}$ \\
\hline $\begin{array}{l}\text { Economic situation } \\
\text { Implications for } \mathrm{L} / \mathrm{U}\end{array}$ & $\begin{array}{l}\text { stagnation and downturn } \\
\text { moderate increasing construction }\end{array}$ & $\begin{array}{l}\text { stable } \\
\text { strong increasing construction }\end{array}$ & $\begin{array}{l}\text { downturn } \\
\text { decreasing construction }\end{array}$ \\
\hline $\begin{array}{l}\text { Tourism } \\
\text { Implications for } \mathrm{L} / \mathrm{U}\end{array}$ & $\begin{array}{l}\text { business as usual } \\
\text { moderate increasing businesses }\end{array}$ & $\begin{array}{l}\text { increasing } \\
\text { strong increasing businesses }\end{array}$ & $\begin{array}{l}\text { decreasing } \\
\text { abandoning businesses }\end{array}$ \\
\hline
\end{tabular}

Table 4. Changes in land use for each scenario as a result of quantified driving forces; bold indicates a decrease and italic an increase of the area. Each value in every time period relates (a) to the total number of cells of the previous time span and (b) to the percentage of land-use class of the total area per time span. For explanation of the abbreviations see Table 1.

\begin{tabular}{|c|c|c|c|c|c|c|c|c|c|}
\hline \multirow{2}{*}{$\begin{array}{l}\text { Timespan } \\
\text { Scenarios }\end{array}$} & & \multirow{2}{*}{$\begin{array}{l}1985-1997 \\
\text { “o”/““+”/““_”" }\end{array}$} & \multirow{2}{*}{$\begin{array}{l}1997-2009 \\
\text { “o”/““+”/““_”” }\end{array}$} & \multicolumn{3}{|c|}{ 2009-2021 } & \multicolumn{3}{|c|}{ 2021-2045 } \\
\hline & & & & "o" & "+" & "-_" & "o" & "+” & "-" \\
\hline MFH & $\begin{array}{l}a \\
b\end{array}$ & $\begin{array}{r}+13 \% \\
7.1 \%\end{array}$ & $\begin{array}{r}+19 \% \\
8.1 \%\end{array}$ & $\begin{array}{r}+13 \% \\
9.5 \%\end{array}$ & $\begin{array}{r}+13 \% \\
9.5 \%\end{array}$ & $\begin{array}{r}+10 \% \\
8.9 \%\end{array}$ & $\begin{array}{r}+8 \% \\
10.2 \%\end{array}$ & $\begin{array}{l}+17 \% \\
+11 \%\end{array}$ & $8.9 \%$ \\
\hline SFH & $\begin{array}{l}a \\
b\end{array}$ & $\begin{array}{r}+33 \% \\
5.3 \%\end{array}$ & $\begin{array}{r}+40 \% \\
7.4 \%\end{array}$ & $\begin{array}{r}+29 \% \\
9.5 \%\end{array}$ & $\begin{array}{r}+29 \% \\
9.5 \%\end{array}$ & $\begin{array}{r}+18 \% \\
8.7 \%\end{array}$ & $\begin{array}{l}+14 \% \\
10.8 \%\end{array}$ & $\begin{array}{l}+33 \% \\
12.6 \%\end{array}$ & $\begin{array}{l}+9 \% \\
9.5 \%\end{array}$ \\
\hline Mix & $\begin{array}{l}\mathrm{a} \\
\mathrm{b}\end{array}$ & $\begin{array}{r}+17 \% \\
7.4 \%\end{array}$ & $\begin{array}{r}+18 \% \\
8.7 \%\end{array}$ & $\begin{array}{r}+15 \% \\
10 \%\end{array}$ & $\begin{array}{r}+15 \% \\
10 \%\end{array}$ & $\begin{array}{l}+9 \% \\
9.5 \%\end{array}$ & $\begin{array}{r}+11 \% \\
11 \%\end{array}$ & $\begin{array}{l}+16 \% \\
11.6 \%\end{array}$ & $\begin{array}{l}+3 \% \\
9.7 \%\end{array}$ \\
\hline Ind & $\begin{array}{l}\mathrm{a} \\
\mathrm{b}\end{array}$ & $\begin{array}{l}-8 \% \\
3.2 \%\end{array}$ & $\begin{array}{l}-8 \% \\
2.9 \%\end{array}$ & $\begin{array}{r}-18 \% \\
2.3 \%\end{array}$ & $\begin{array}{r}-18 \% \\
2.3 \%\end{array}$ & $2.9 \%$ & $\begin{array}{l}-8 \% \\
2.1 \%\end{array}$ & $\begin{array}{l}-8 \% \\
2.1 \%\end{array}$ & $2.9 \overline{\%}$ \\
\hline Rail & $\begin{array}{l}a \\
b\end{array}$ & $2 \%$ & $\begin{array}{r}-11 \% \\
2.1 \%\end{array}$ & $2.1 \%$ & $2.1 \%$ & $2.1 \%$ & $2.1 \%$ & $2.1 \%$ & $\begin{array}{r}- \\
2.1 \%\end{array}$ \\
\hline Road & $\begin{array}{l}a \\
b\end{array}$ & $\begin{array}{r}+13 \% \\
3.5 \%\end{array}$ & $\begin{array}{l}-6 \% \\
3.2 \%\end{array}$ & $\begin{array}{l}+7 \% \\
3.5 \%\end{array}$ & $\begin{array}{l}+7 \% \\
3.5 \%\end{array}$ & $3.2 \%$ & $3.5 \%$ & $\begin{array}{r}-19 \% \\
2.7 \%\end{array}$ & $3.2 \%$ \\
\hline Agri & $\begin{array}{l}\mathrm{a} \\
\mathrm{b}\end{array}$ & $\begin{array}{l}-18 \% \\
18.2 \%\end{array}$ & $\begin{array}{l}-20 \% \\
14.7 \%\end{array}$ & $\begin{array}{l}-33 \% \\
10.2 \%\end{array}$ & $\begin{array}{l}-33 \% \\
10.2 \%\end{array}$ & $\begin{array}{l}-24 \% \\
11.5 \%\end{array}$ & $\begin{array}{r}-37 \% \\
6.9 \%\end{array}$ & $\begin{array}{r}-37 \% \\
5 \%\end{array}$ & $\begin{array}{l}-36 \% \\
7.9 \%\end{array}$ \\
\hline For & $\begin{array}{l}a \\
b\end{array}$ & $\begin{array}{r}+<1 \% \\
35.2 \%\end{array}$ & $\begin{array}{r}+<1 \% \\
35.5 \%\end{array}$ & $\begin{array}{r}+<1 \% \\
35.7 \%\end{array}$ & $\begin{array}{r}+<1 \% \\
35.7 \%\end{array}$ & $\begin{array}{r}+<1 \% \\
35.7 \%\end{array}$ & $\begin{array}{r}+2 \% \\
36.2 \%\end{array}$ & $\begin{array}{r}- \\
35.7 \%\end{array}$ & $\begin{array}{r}+7 \% \\
38.3 \%\end{array}$ \\
\hline Unprod & $\begin{array}{l}a \\
b\end{array}$ & $\begin{array}{r}- \\
18.1 \%\end{array}$ & $\begin{array}{r}-3 \% \\
17.5 \%\end{array}$ & $\begin{array}{r}-2 \% \\
17.2 \%\end{array}$ & $\begin{array}{r}-2 \% \\
17.2 \%\end{array}$ & $\begin{array}{r}- \\
17.5 \%\end{array}$ & $\begin{array}{r}- \\
17.2 \%\end{array}$ & $\begin{array}{r}- \\
17.2 \%\end{array}$ & $17.5 \%$ \\
\hline
\end{tabular}

"agriculture" was modelled to lose even larger areas in future time spans than during past decreases. Correspondingly, 18$37 \%$ of the new settlement development took place on formerly agricultural land. "Industry" was projected to decrease in the scenarios "o" and "+" until 2045. "Forest", "unproductive area", "railway" and "roads" did not experience important changes between past and future time spans in any scenario. Generally, the rate of increase in specific land-use classes slowed down with time due to the absolute growth of their respective areas. The scenarios "o" and "+" introduced the same changes in all land-use classes until 2021; afterwards their development started to differ. Scenario "-" developed independent characteristics from the beginning of the modelling (2009) as it is the only scenario including economic downturn.
The results of the allocation of the scenarios for the year 2045 are shown in Fig. 5 and compared with land use in 2009. All scenarios implied changes in similar land-use classes, mainly in "settlements". The changes mainly occurred at the expense of "agriculture". The strong increase in "single-family houses" occurred in the eastern and the northern parts of Naters, where construction was legally approved after 1997. Particularly in the scenario "+" the total number of cells increased by about 29 and $33 \%$ up to 2021 and 2045, respectively, while "multi-family houses" expanded and aggregated in the area along the river Rhône at the southern border of Naters. This development was similar for all scenarios up to 2021, where the total number of cells increased by about 10-13\%. After 2021 however, this development only continued in the scenarios "o" and "+" (8 and 17\%), while "multi-family house" construction stopped in scenario 
"_". The same development was also modelled for "mixed use", where already existing zones expanded along the river in addition to increasing "mixed use" areas in the centre of the village. Change rates were least in the scenario "-" $(+9$ and $+3 \%)$ and highest $(+15$ and $+16 \%)$ in the scenario "+" in both time steps.

\subsection{Risk estimation}

The flood intensity estimations showed (Figs. $1 \mathrm{~b}$ and c) that the biggest part of the study area will be affected in the case of a GLOF, independent of the outburst scenario (4 or 20 million $\mathrm{m}^{3}$ ). The height of the flood varies between $1 \mathrm{~m}$ and approximately $14 \mathrm{~m}$ in narrow passages. In both GLOF scenarios a maximum estimated retention volume of 2 million $\mathrm{m}^{3}$ by the barrier lake Gibidum was considered. Thereby, a 1.5 million $\mathrm{m}^{3}$ flood draining through Gibidum lake would cause high flood intensities (inundation heights $>2 \mathrm{~m}$ ) in Naters. Accordingly, high flood intensities were mapped for half, and for most of the area affected in the case of an outburst flood of 4 and 20 million $\mathrm{m}^{3}$ respectively. GLOF travel times were calculated based on a range of 3$6 \mathrm{~m} \mathrm{~s}^{-1}$ average flow velocity (Cenderelli and Wohl, 2001; Schneider et al., 2014), depending on factors such as sediment concentration and flow volume, resulting in $40-80 \mathrm{~min}$ travel time.

In all scenarios, the highest values for the factor loss were mostly modelled in the central part of Naters, where most "settlements" are located (Fig. 6). The most striking difference between values for persons and for objects can be seen in "mixed use", which varied between high (persons) and intermediate (object value) according to the classification presented in Table 2.

Only very few areas showed low or intermediate physical vulnerability against a GLOF in any scenario. Very high physical vulnerability, however, was predominantly present at the marginal areas of the case study area, as it mostly belongs to "forests", "agriculture" and "unproductive areas". The allocation of high vulnerability levels to the above landuse classes is not made consistently through the international literature but here it was done in the sense of the definition (impairment of an object as affected by a hazard process), and because it is in line with the official government guidelines in Switzerland, i.e. the platform EconoMe (BAFU, 2011). "Multi-family houses" also featured very high physical vulnerability and were located in the areas very close to the river Rhône. Furthermore, virtually the entire centre of Naters showed high physical vulnerability, as it consisted mainly of "single-family houses" and "mixed use".

High and very high social vulnerability clusters in the central part of Naters, which is basically due to the high density of "multi-family houses" and "single-family houses" in this area.

According to the approach outlined in Sect. 3 two risk maps were generated, based on the two versions of the risk

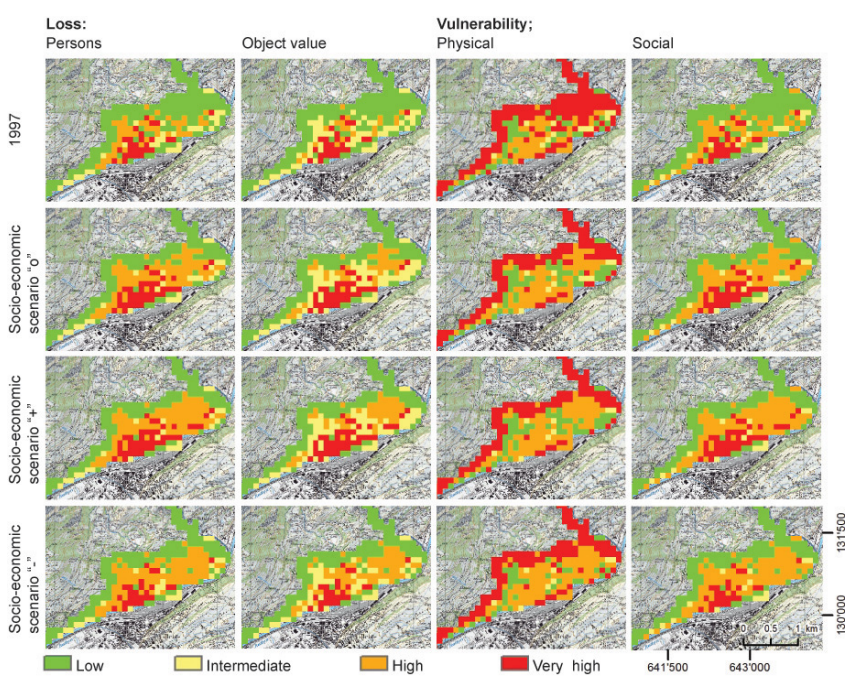

Figure 6. Spatial allocation of the assessment variables loss and vulnerability following the four-level scale defined in Table 2. DEM25 reproduced with permission of Swisstopo (BA110005) and BFS (1986, 1998).

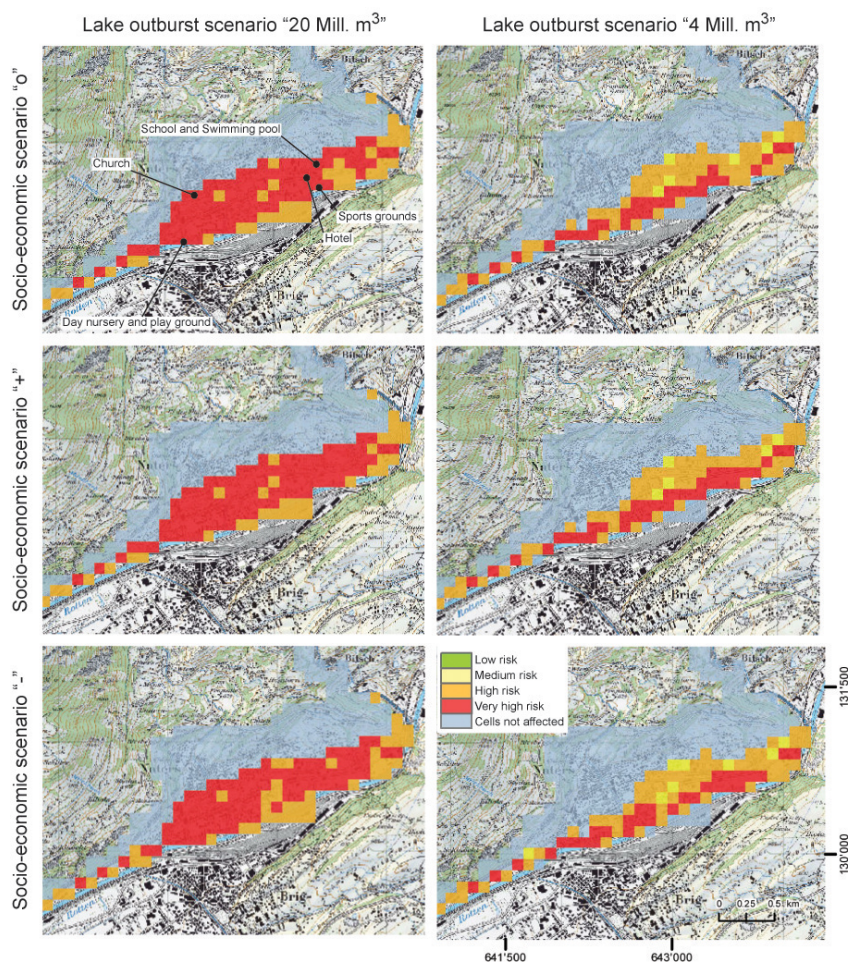

Figure 7. Risk for Naters in 2045 for lake outbursts considering the risk matrix (a) in Fig. 4. The three rows indicate the socio-economic scenarios "o", "+" and "-", the two columns the lake outburst scenarios with 20 and 4 million $\mathrm{m}^{3}$. Arrows indicate hotspot locations of social vulnerability. Reproduced with permission of Swisstopo (BA110005) and BFS (1986, 1998).

matrices (Fig. 4). The first risk map (Fig. 7) was based on the matrix (a) in Fig. 4, representing intensity values of 2 and 4, and showed high to very high risk in each socio-economic 
Table 5. Affected area per risk category as well as per land-use and intensity scenario. Total case study area $=2.88 \mathrm{~km}^{2}$. Values in percent only refer to the affected area. The upper and the lower part of the table refer to the risk matrices (a) and (b) applying the intensity values 2 and 4 and 1 and 3 respectively.

\begin{tabular}{|c|c|c|c|c|c|c|c|c|c|c|c|c|}
\hline \multirow[t]{3}{*}{ Risk category } & \multicolumn{4}{|c|}{ Scenario "o" } & \multicolumn{4}{|c|}{ Scenario "+" } & \multicolumn{4}{|c|}{ Scenario “-" } \\
\hline & \multicolumn{2}{|c|}{4 million $\mathrm{m}^{3}$} & \multicolumn{2}{|c|}{20 million $\mathrm{m}^{3}$} & \multicolumn{2}{|c|}{4 million $\mathrm{m}^{3}$} & \multicolumn{2}{|c|}{20 million $\mathrm{m}^{3}$} & \multicolumn{2}{|c|}{4 million $\mathrm{m}^{3}$} & \multicolumn{2}{|c|}{20 million $\mathrm{m}^{3}$} \\
\hline & $\%$ & $\mathrm{~km}^{2}$ & $\%$ & $\mathrm{~km}^{2}$ & $\%$ & $\mathrm{~km}^{2}$ & $\%$ & $\mathrm{~km}^{2}$ & $\%$ & $\mathrm{~km}^{2}$ & $\%$ & $\mathrm{~km}^{2}$ \\
\hline \multicolumn{13}{|l|}{ (a) risk matrix } \\
\hline $1=$ low & 0 & 0 & 0 & 0 & 0 & 0 & 0 & 0 & 0 & 0 & 0 & 0 \\
\hline $2=$ medium & 2.1 & 0.06 & 0 & 0 & 1.7 & 0.05 & 0 & 0 & 2.8 & 0.08 & 0 & 0 \\
\hline $3=$ high & 24.0 & 0.69 & 18.4 & 0.53 & 22.9 & 0.66 & 16.7 & 0.48 & 23.3 & 0.67 & 19.1 & 0.55 \\
\hline $4=$ very high & 10.4 & 0.30 & 28.5 & 0.82 & 11.8 & 0.34 & 30.2 & 0.87 & 10.4 & 0.30 & 27.8 & 0.80 \\
\hline No value & 63.5 & 1.83 & 53.1 & 1.53 & 63.5 & 1.83 & 53.1 & 1.53 & 63.5 & 1.83 & 53.1 & 1.53 \\
\hline \multicolumn{13}{|l|}{ (b) risk matrix } \\
\hline $1=$ low & 0 & 0 & 0 & 0 & 0 & 0 & 0 & 0 & 0 & 0 & 0 & 0 \\
\hline $2=$ medium & 9.0 & 0.26 & 1.4 & 0.04 & 5.9 & 0.17 & 1.7 & 0.05 & 11.5 & 0.33 & 1.4 & 0.04 \\
\hline $3=$ high & 21.9 & 0.63 & 32.3 & 0.93 & 24.7 & 0.71 & 26.4 & 0.76 & 21.2 & 0.61 & 37.2 & 1.07 \\
\hline $4=$ very high & 5.6 & 0.16 & 13.2 & 0.38 & 5.9 & 0.17 & 18.8 & 0.54 & 3.8 & 0.11 & 8.3 & 0.24 \\
\hline No value & 63.5 & 1.83 & 53.1 & 1.53 & 63.5 & 1.83 & 53.1 & 1.53 & 63.5 & 1.83 & 53.1 & 1.53 \\
\hline
\end{tabular}

and intensity scenario for a large area of Naters. For the larger scenario, i.e. a GLOF of 20 million $\mathrm{m}^{3}$, the affected area equalled approx. $47 \%$ of the total study area (Table 5). No low or intermediate risk was modelled; between 16 and $20 \%$ of the total study area was assumed to be affected by high and around $30 \%$ by very high risk. In the case of the smaller scenario, i.e. a GLOF of 4 million $\mathrm{m}^{3}$, very high risk affected around $11 \%$ of the entire study area, whereas the total affected area only equalled around $37 \%$ of the entire study area. Some limited areas were found to feature intermediate risk, which was not found for the 20 million $\mathrm{m}^{3}$ scenario. While for the smaller scenario very high risk areas mostly accumulated along the river, the highest risk class covers substantial areas of the municipality for the larger scenario. The objects of special interest and of particular vulnerability are highlighted in Fig. 7 and include a church, school and hotel which are found in areas of high to very high risk.

It is interesting to note that for this version of the risk map the socio-economic scenarios do not exert an important influence on the final risk estimate. This is different for the second version of the risk maps (Fig. 8) in which intensity values of 1 and 3 according to matrix (b) were implemented. Here, risk maps substantially differ depending on the socioeconomic scenario used. For the larger hazard scenario (i.e. a GLOF of 4 million $\mathrm{m}^{3}$ ) very high risk was only modelled for those parts of the city centre which were close to the river, amounting to about $5 \%$ of the case study area. Considerable parts of Naters $(9,6$, and $12 \%$ for the socio-economic scenario "o", “+", and "-", respectively) were modelled to be affected by intermediate risk. In the case of a GLOF of 20 million $\mathrm{m}^{3}$ only small areas (of around $1.5 \%$ ) of intermediate risk were distinguished, contrary to the first risk maps

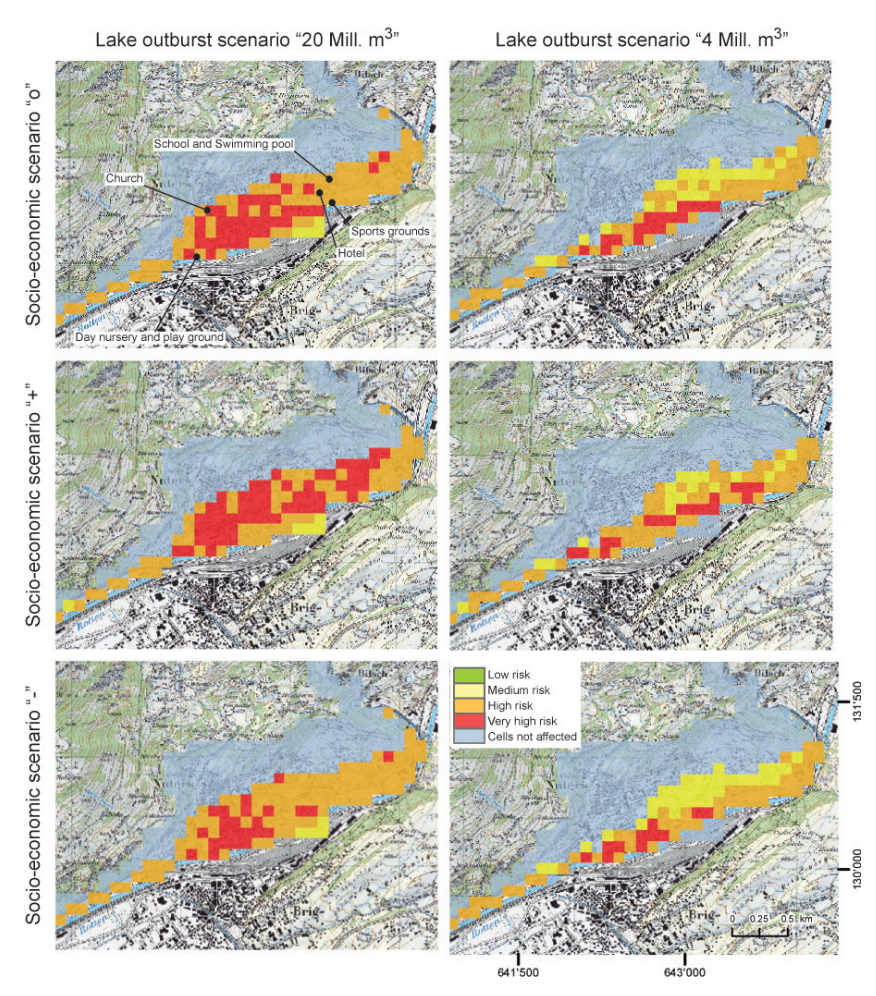

Figure 8. Risk for Naters in 2045 for lake outbursts considering the risk matrix (b) in Fig. 4. The three rows indicate the socio-economic scenarios "o", "+", and "-", the two columns the lake outburst scenarios with 20 and 4 million $\mathrm{m}^{3}$. Arrows indicate hotspot locations of social vulnerability. Reproduced with permission of Swisstopo (BA110005) and BFS (1986, 1998). 
(Fig. 7) which did not feature any intermediate risk. Across all socio-economic scenarios in the larger hazard scenario, very high risk was mainly concentrated in the city centre and amounted to 13,19 , and $8 \%$ of the study area for the socioeconomic scenarios "o", “+”, and “-”, respectively.

\section{Discussion and conclusions}

In this study a method was developed to assess local-scale damage potential as defined by changing land-use conditions, and consequent future risks related to floods from GLOFs. An extensive review of existing methodologies revealed that there was no adequate approach available which could directly be applied for the purpose of this study. An important body of research on land-use modelling including the assessment of driving forces, scenario development and allocation of change in space is available. Existing land-use models explore the possible changes in the future and at a range of scales but rarely with the primary objective of quantifying damage potential related to natural hazards.

Regarding hazard assessment, recent studies on GLOF processes and GLOF modelling mainly focus on already existing lakes (e.g. Osti and Egashira, 2009; Worni et al., 2012). Studies on the assessment of local-scale hazards from floods from future lakes are currently a research gap. Therefore, one of the main challenges of this study was to develop, adapt and apply methods from two different scientific fields, i.e. landuse change and GLOF research, to achieve the assessment of associated future risks.

The assessment of hazards related to outbursts of future glacier lakes involves substantial uncertainties. However, results from models of glacier shrinkage and lake formation are relatively robust for a glacier of the size of Grosser Aletsch. As confirmed by multiple model runs, the exact location of a future glacier lake (as subject to uncertainty) does not have a critical effect on flood intensities in Naters. Uncertainties related to GLOF volume were accommodated by defining different outburst scenarios, an approach that is also applied for present-day lake outburst flood hazards (Schneider et al., 2014) and that is generally recommended in situations of problematic knowledge on probabilities (Stirling, 2007). GLOF travel times can also vary by about a factor of 2 or more. Larger flood scenarios tend to show higher flow velocities, and thus shorter travel times, which translates into shorter lead time for warning (Schneider et al., 2014).

Uncertainties are also substantial with respect to future damage potential, the second component of the risk assessment. Similarly to the hazard assessment, scenarios were defined to cover a range of different land-use trajectories. Definition of scenarios is to some degree arbitrary, therefore an approach that increases consistency was pursued. The most important driving forces of land-use change of this case study were local, regional, national and international economy, and decisions taken by civil society, policy and juris- diction (Holzer, 2011; Michlig, 2011). Agriculture, economy and tourism were assessed to be related to those drivers, but on the other hand also drive land-use changes in Naters. The socio-economically driven land-use scenarios were backed by literature-based findings, interviews with local authorities and plausibility tests. Therefore, they were assumed to represent a relatively robust range of possible future outcomes, including the extrapolation of current development. As development in all scenarios remained restricted to the current planning zones, even the scenario "+" has to be considered relatively conservative. More "extreme" scenarios and time horizons beyond 2045 were not considered as the corresponding assumptions would have been more speculative and the respective time horizon less relevant for policy makers. Based on the assessment of driving forces and development of scenarios, land-use transformation rates were quantified and changes in space allocated, using a rule-based model, and considering constraints such as legally defined construction zones.

Land-use scenarios were calculated semi-quantitatively while hazard and risk estimations were based on qualitative matrices. The resulting risk maps included the spatial distribution and the variability of different risk categories. Two risk matrices were applied to demonstrate the effects of (subjective) definition of risk class distribution in the matrix. Results showed that the definition of risk matrices can have a substantial effect on risk results. A risk matrix more strongly weighted towards high risk classes (matrix a) can exert a dominant effect over socio-economic, while a more balanced risk matrix (b) quite obviously reduces the proportion of (very) high risk areas and gives higher weight to the effects of socio-economic development. Based on this analysis, a balanced risk matrix would probably be preferable; however, it should be underlined that the definition and choice of risk weighting is ultimately a task of policy and society and not science (Künzler et al., 2012).

In the context of integrated risk management, a risk analysis is not an endpoint but forms an input for risk reduction measures. The results of this study indicated the important difference between smaller and larger GLOF scenarios in terms of risks encountered in Naters. Accordingly, authorities may also consider investments to prevent large GLOFs reaching the urban areas of Naters, such as by structural measures. However, structural measures might not always be applicable or legally feasible due to various reasons such as costs involved, environmental protection areas or private property. Therefore, strategies to reduce risks of loss of lives by increasing the people's preparedness, once the new glacier lakes form, may be of relevance (e.g. IPCC, 2012). Experiences have shown that early warning systems for GLOFs can be effective to achieve risk reduction (e.g. Kattelmann, 2003), mainly by decreasing the number of persons exposed. The GLOF travel time estimates indicated warning lead times of about $40-80 \mathrm{~min}$, where smaller and larger flood scenarios again make a difference. This range of 
warning lead time is considered feasible for an operational early warning system and confirms the potential to reduce risks to future GLOF hazards.

While the value and physical vulnerability of objects possibly affected will typically remain unchanged with an early warning system, the exposure probability of people should be substantially reduced with such risk reduction measures. The exposure probability in the case of early warning is related to people's preparedness, and thus could be considered in terms of social vulnerability. Research (e.g. from Hurricane Katrina in 2005) indicates that social aspects such as welfare and social class exert an important effect on response to disasters, including evacuation timing (Elliot and Pais, 2006). For this study an early warning system in place has not been considered in the scenarios but may be integrated in future research. Avoidance of high-loss and high-vulnerability assets in flood-prone areas is most important to reduce high and very high risks (e.g. CIPRA, 2010; ARE and UVEK, 2008), especially if structural mitigation measures might not be very feasible. The avoided damage can be estimated from the risk analysis based on the different scenarios.

Overall, this study corroborates the fundamental importance of land-use policies and governance for risk reduction (e.g. BUWAL, 2003; OcCC, 2007). In the case of highdevelopment trajectories a main challenge for policy will be to counteract certain driving forces. This study can represent a contribution for local, rural development planning, if additional information on risks related to other natural hazards as well as the coordination with further development plans of the community are considered.

Acknowledgements. This study was carried out within the project New Lakes (NELAK, 406140_125997), which was funded by the Swiss National Science Foundation and UNISCIENTIA STIFTUNG within the framework of the National Research Programme 61 on sustainable water management. We thank Wilfried Haeberli and several other project colleagues for valuable inputs and discussions. We also thank Martin Mergili, Norman Kerle (editor) and an anonymous reviewer for thoughtful critiques of the paper.

Edited by: N. Kerle

Reviewed by: M. Mergili and one anonymous referee

\section{References}

Alcamo, J.: Scenarios as a tool for international environmental assessments, experts' corner report, Prospects and Scenarios No 5, Environmental Issue Report No 24, European Environmental Agency (EEA), Kopenhagen, 2001.

ARE and UVEK: Raumkonzept Schweiz: Eine dynamische und solidarische Schweiz, Entwurf, Bundesamt für Raumentwicklung (ARE) und Eidgenössisches Departement für Umwelt, Verkehr, Energie und Kommunikation (UVEK), Bern, 2008 (in German).
BAFU: Wirtschaftlichkeit von Schutzmassnahmen gegen Naturgefahren: EconoMe 2.1, Bundesamt für Umwelt (BAFU), available at: www.econome.admin.ch/index.php, last access: 4 June 2014, 2011.

Bara, C.: Factsheet: Social Vulnerability to disasters, CRN Report, Crisis and Risk Network (CRN), Center for Security Studies (CSS) and Swiss Federal Institute of Technology Zürich (ETH), Zurich, 2010.

BFS: GEOSTAT, Arealstatistik 1979/1985, Bundesamt für Statistik (BFS), Neuchâtel, 1986 (in German).

BFS: GEOSTAT, Arealstatistik 1992/1997, Bundesamt für Statistik (BFS), Neuchâtel, 1998 (in German).

BFS: Erhebungen, Quellen - Arealstatistik der Schweiz: Steckbrief, Bundesamt für Statistik (BFS), available at: http://www.bfs.admin.ch/bfs/portal/de/index/infothek/ erhebungenlquellen/blank/blank/arealstatistik/01.html, last access: 27 February 2014, 2011 (in German).

Bouwer, L. M., Bubeck, P., and Aerts, J. C. J. H.: Changes in future flood risk due to climate and development in a Dutch polder area, Global Environ. Chang., 20, 463-471, doi:10.1016/j.gloenvcha.2010.04.002, 2010.

Briner, S., Elkin, C., Huber, R., and Grêt-Regamey, A.: Assessing the impacts of economic and climate changes on land-use in mountain regions: A spatial dynamic modeling approach, Agr. Ecosyst. Environ., 149, 50-63, 2012.

Britz, W., Verburg, P., and Leip, A.: Modelling of land cover and agricultural change in Europe: combining the CLUE and CAPRISpat approaches, Agr. Ecosyst. Environ., 142, 40-50, 2011.

Bründl, M. (Ed.): Risikokonzept für Naturgefahren Leitfaden, Nationale Plattform für Naturgefahren (PLANAT), Bern, 2009 (in German).

Burgerschaft Naters: Wälder, available at: http://www. burgerschaft-naters.ch/?id=22, last access: 4 June 2014, 2011 (in German).

BUWAL (Ed.): Landschaft 2020 - Analysen und Trends, Grundlagen zum Leitbild des BUWAL für Natur und Landschaft, Schriftenreihe Umwelt Nr. 352, Bundesamt für Umwelt, Wald und Landschaft (BUWAL), Bern, 2003 (in German).

Cammerer, H., Thieken, A. H., and Verburg, P. H.: Spatio-temporal dynamics in the flood exposure due to land use changes in the Alpine Lech Valley in Tyrol (Austria), Nat. Hazards, 68, 12431270, doi:10.1007/s11069-012-0280-8, 2012.

Carey, M.: Living and dying with glaciers: people's historical vulnerability to avalanches and outburst floods in Peru, Global Planet. Change, 47, 122-134, 2005.

Carter, T., la Rovere, E. L., Jones, R. N., Leemans, R., Mearns, L. O., Nakicenovic, N., Pittock, A. B., Semenov, S. M., and Skea, J.: Developing and applying scenarios, in: Climate Change 2001: Impacts, Adaptation and Vulnerability, contribution of Working Group II to the Fourth Assessment Report of the Intergovernmental Panel on Climate Change, edited by: McCarthy, J. J., Canziani, O. F., Leary, N. A., Dokken, D. J., and White, K. S., Cambridge University Press, Cambridge, 145-190, 2001.

Cenderelli, D. A. and Wohl, E. E.: Peak discharge estimates of glacial-lake outburst floods and "normal" climatic floods in the Mount Everest region, Nepal, Geomorphology, 40, 57-90, 2001. CIPRA (Ed.): Spatial planning in climate change: A CIPRA background report, COMPACT, No. 02, 2010. 
Clague, J. J., Huggel, C., Korup, O., and McGuire, B.: Climate change and hazardous processes in high mountains, Revista de la Asociación Geológica Argentina, 69, 328-338, 2012.

Cutter, S., Emrich, C., Webb, J., and Morath, D.: Social Vulnerability to Climate Variability Hazards: A Review of the Literature, Final Report to Oxfam America, Hazards and Vulnerability Research Institute Department of Geography (HVRI), University of South Carolina, Columbia, 2009.

Elliott, J. R. and Pais, J.: Race, class, and Hurricane Katrina: Social differences in human responses to disaster, Soc. Sci. Res., 35, 295-321, 2006.

Fontaine, C. M. and Rounsevell, M. D. A.: An agent-based approach to model future residential pressure on a regional landscape, Landscape Ecol., 24, 1237-1254, 2009.

Frey, H., Haeberli, W., Linsbauer, A., Huggel, C., and Paul, F.: A multi-level strategy for anticipating future glacier lake formation and associated hazard potentials, Nat. Hazards Earth Syst. Sci., 10, 339-352, doi:10.5194/nhess-10-339-2010, 2010.

Gardner, A. S., Moholdt, G., Cogley, J. G., Wouters, B., Arendt, A. A., Wahr, J., Berthier, E., Hock, R., Pfeffer, W. T., Kaser, G., Ligtenberg, S. R. M., Bolch, T., Sharp, M. J., Hagen, J. O., van den Broeke, M. R., and Paul, F.: A Reconciled Estimate of Glacier Contributions to Sea Level Rise: 2003 to 2009, Science, 340, 852-857, doi:10.1126/science.1234532, 2013.

Haeberli, W.: Mountain permafrost - research frontiers and a special long-term challenge, Cold Reg. Sci. Technol., 96, 71-76, doi:10.1016/j.coldregions.2013.02.004, 2013.

Haeberli, W. and Linsbauer, A.: Brief communication "Global glacier volumes and sea level - small but systematic effects of ice below the surface of the ocean and of new local lakes on land", The Cryosphere, 7, 817-821, doi:10.5194/tc-7-817-2013, 2013.

Haeberli, W., Clague, J. J., Huggel, C., and Kääb, A.: Hazards from lakes in high-mountain glacier and permafrost regions: climate change effects and process interactions, Avances de la Geomorphología en España, 2008-2010, XI Reunión Nacional de Geomorphología, Solsona, 439-446, 2010.

Harris, C., Arenson, L. U., Christiansen, H. H., Etzelmüller, B., Frauenfelder, R., Gruber, S., Haeberli, W., Hauck, C., Hölzle, M., Humlum, O., Isaksen, K., Kääb, A., Kern-Lütschg, M. A., and Lehning, M.: Permafrost and climate in Europe: Monitoring and modelling thermal, geomorphological and geotechnical responses, Earth-Sci. Rev., 92, 117-171, 2009.

Hegglin, E. and Huggel, C.: An Integrated Assessment of Vulnerability to Glacial Hazards: A case Study in the Cordillera Blanca, Peru, Mt. Res. Dev., 28, 299-309, 2008.

Henderson, M. F.: Open Channel Flow, MacMillan, New York, 1966.

Holzer, M.: Oral statements about land-use development scenarios in Naters, interview, Naters, 11 July 2011 (in German).

Huggel, C., Kääb, A., Haeberli, W., Teysseire, P., and Paul, F.: Remote sensing based assessment of hazards from glacier lake outbursts: a case study in the Swiss Alps, Can. Geotech. J., 39, 316330, 2002.

Huggel, C., Kääb, A., Haeberli, W., and Krummenacher, B.: Regional-scale GIS-models for assessment of hazards from glacier lake outbursts: evaluation and application in the Swiss Alps, Nat. Hazards Earth Syst. Sci., 3, 647-662, doi:10.5194/nhess-3-647-2003, 2003.
Huggel, C., Haeberli, W., Kääb, A., Bieri, D., and Richardson, S.: An assessment procedure for glacial hazards in the Swiss Alps, Can. Geotech. J., 41, 1068-1083, 2004.

Huggel, C., Blaškovičová, L., Breien, H., Dobesberger, P., Frauenfelder, R., Kalsnes, B. G., Solheim, A., Štastný, P., and Kronholm, K.: Glacier floods, in: Impacts of climate change on snow, ice, and permafrost in Europe: Observed trends, future projections, and socio-economic relevance, edited by: Voigt, T., Füssel, H.-M., Gärtner-Roer, I., Huggel, C., Marty, C., and Zemp, M., European Environment Agency, Copenhagen, 102-106, 2011.

Huggel, C., Clague, J. J., and Korup, O.: Is climate change responsible for changing landslide activity in high mountains?, Earth Surf. Proc. Land., 37, 77-91, 2012.

Hunziker, M.: The spontaneous reafforestation in abandoned agricultural lands: perception and aesthetic assessment by locals and tourists, Landscape Urban Plan., 31, 399-410, 1995.

IPCC: Managing the Risks of Extreme Events and Disasters to Advance Climate Change Adaptation, A Special Report of Working Groups I and II of the Intergovernmental Panel on Climate Change, edited by: Field, C. B., Barros, V., Stocker, T. F., Qin, D., Dokken, D. J., Ebi, K. L., Mastrandrea, M. D., Mach, K. J., Plattner, G.-K., Allen, S. K., Tignor, M., and Midgley, P. M., Cambridge University Press, Cambridge, UK, and New York, NY, USA, 2012.

Kantonsforstamt St. Gallen: Waldeigentum, available at: http:// www.wald.sg.ch/home/waldeigentum.html, last access: 4 June 2014, 2011.

Kattelmann, R.: Glacial Lake Outburst Floods in the Nepal Himalaya: A Manageable Hazard?, Nat. Hazards, 28, 145-154, 2003.

Künzler, M., Huggel, C., Linsbauer, A., and Haeberli, W.: Emerging risks related to new lakes in deglaciating areas of the Alps, in: Mountain Risks: Bringing Science to Society, Proceedings of the "Mountain Risk" International Conference, 24-26 November 2010, Firenze, Italy, edited by: Malet, J.-P., Glade, T., and Casagli, N., CERG Editions, Strasbourg, France, 453-458, 2010.

Künzler, M., Huggel, C., and Ramírez, J. M.: A risk analysis for floods and lahars: case study in the Cordillera Central of Colombia, Nat. Hazards, 64, 767-796, 2012.

Leitungsgruppe des NFP 48 (Ed.): Landschaften und Lebensräume der Alpen - Zwischen Wertschöpfung und Wertschätzung, Reflexionen zum Abschluss des Nationalen Forschungsprogramms 48, Schweizerischer Nationalfonds zur Förderung des wissenschaftlichen Forschung (FNSNF), 2007 (in German).

Linsbauer, A., Paul, F., Machguth, H., and Haeberli, W.: Comparing three different methods to model scenarios of future glacier change in the Swiss Alps, Ann. Glaciol., 54, 241-253, 2013.

Loat, L. and Petrascheck, A.: Berücksichtigung der Hochwassergefahren bei raumwirksamen Tätigkeiten, Empfehlungen 1997, Naturgefahren. Bundesamt für Wasserwirtschaft (BWW), Bundesamt für Raumplanung (BRP) und Bundesamt für Umwelt, Wald und Landschaft (BUWAL), Biel, 1997 (in German).

McKillop, R. and Clague, J. J.: A procedure for making objective preliminary assessments of outburst flood hazard from morainedammed lakes in southwestern British Columbia, Nat. Hazards, 41, 131-157, doi:10.1007/s11069-006-9028-7, 2007.

Mergili, M. and Schneider, J. F.: Regional-scale analysis of lake outburst hazards in the southwestern Pamir, Tajikistan, based on 
remote sensing and GIS, Nat. Hazards Earth Syst. Sci., 11, 14471462, doi:10.5194/nhess-11-1447-2011, 2011.

Michlig, D.: Oral statements about land-use development scenarios in Naters, interview, Naters, 11 July 2011 (in German).

Nöthiger, C., Elsasser, H., Bründl, M., und Ammann, W.: Indirekte Auswirkungen von Naturgefahren auf den Tourismus - Das Beispiel des Lawinenwinters 1999 in der Schweiz, Geographica Helvetica, 57, 91-108, 2002 (in German).

OcCC: Klimaänderung und die Schweiz 2050: Erwartete Auswirkungen auf Umwelt, Gesellschaft und Wirtschaft, Organe consultatif sur les changements climatiques (OcCC) und Forum für Klima und Global Change (ProClim), Bern, 2007 (in German).

Osti, R. and Egashira, S.: Hydrodynamic characteristics of the Tam Pokhari glacial lake outburst flood in the Mt. Everest region, Nepal, Hydrol. Process., 23, 2943-2955, doi:10.1002/hyp.7405, 2009.

Schaub, Y., Haeberli, W., Huggel, C., Künzler, M., and Bründl, M.: Landslides and new lakes in deglaciating areas: a risk management framework, in: Proceedings of the Second World Landslide Forum, 3-7 October 2011, Rome, Italy, 2013.

Schneider, D., Huggel, C., Cochachin, A., Guillén, S., and García, J.: Mapping hazards from glacier lake outburst floods based on modelling of process cascades at Lake 513, Carhuaz, Peru, Adv. Geosci., 35, 145-155, doi:10.5194/adgeo-35-145-2014, 2014.

Soares-Filho, B. S., Nepstad, D., Curran, L., Voll, E., Cerqueira, G., Garcia, R. A., Ramos, C. A., Mcdonald, A., Lefebvre, P., and Schlesinger, P.: Modeling conservation in the Amazon basin, Nature, 440, 520-523, 2006.

Stirling, A.: Risk, precaution and science: towards a more constructive policy debate, EMBO Rep., 8, 309-315, 2007.

Stoffel, M. and Huggel, C.: Effects of climate change on mass movements in mountain environments, Prog. Phys. Geog., 36, 421-439, 2012.

Strozzi, T., Delaloye, R., Kääb, A., Ambrosi, C., Perruchoud, E., and Wegmüller, U.: Combined observations of rock mass movements using satellite SAR interferometry, differential GPS, airborne digital photogrammetry, and airborne photography interpretation, J. Geophys. Res., 115, F01014, doi:10.1029/2009JF001311, 2010.
Swisstopo: DEM25 - The digital height model of Switzerland, Federal Office of Topography (swisstopo), Wabern, Switzerland, 2010.

UNISDR: 2009 UNISDR Terminology on Disaster Risk Reduction. United Nations International Strategy for Disaster Reduction (UNISDR), Geneva, Switzerland, 2009.

Voigt, T., Füssel, H. M., Gärtner-Roer, I., Huggel, C., Marty, C., and Zemp, M.: Impacts of climate change on snow, ice, and permafrost in Europe: Observed trends, future projections, and socio-economic relevance, ETC/ACC Technical Paper 2010/2013. European Topic Centre on Air and Climate Change (ETC/ACC), Bilthoven, Netherlands, 2010.

Walz, A., Lardelli, C., Behrendt, H., Lundstöm, C., Grêt-Regamey, A., Kytzia, S., and Bebi, P.: Participatory scenario analysis for integrated regional modelling, Landscape Urban Plan., 81, 114 131, 2007.

Walz, A., Brand, F., Braendle, J., Briner, S., Elkin, C., Hirschi, C., Lischke, H., Schmatz, D., and Lang, D.: Experience from customising IPCC scenarios to specific national-level focus scenarios for ecosystem service management, Technol. Forecast. Soc., in press, 2013.

WGMS and UNEP: Global glacier changes: facts and figures, in: United Nations Environment Programme UNEP, edited by: Zemp, M., Roer, I., Kääb, A., Hoelzle, M., Paul, F., and Haeberli, W., World Glacier Monitoring Service WGMS, University of Zurich, Switzerland, 2008.

Wissen Hayek, U. W., Jaeger, J. A. G., Schwick, C., Jarne, A., and Schuler, M.: Measuring and Assessing Urban Sprawl: What are the Remaining Options for Future Settlement Development in Switzerland for 2030?, Applied Spatial Analysis and Policy, 4, 249-279, 2011.

Worni, R., Huggel, C., Stoffel, M., and Pulgarín, B.: Challenges of modeling current very large lahars at Nevado del Huila Volcano, Colombia, B. Volcanol., 74, 309-324, doi:10.1007/s00445-0110522-8, 2012.

Zemp, M., Hoelzle, M., and Haeberli, W.: Distributed modelling of the regional climatic equilibrium line altitude of glaciers in the European Alps, Global Planet. Change, 56, 83-100, doi:10.1016/j.gloplacha.2006.07.002, 2007. 